Article

\title{
Power Quality Performance of Fast-Charging under Extreme Temperature Conditions
}

\author{
Alexandre Lucas *, Germana Trentadue, Harald Scholz and Marcos Otura \\ European Commission, Joint Research Centre Directorate C Energy, Transport and Climate, PO Box 2, \\ 1755 ZG Petten, The Netherlands; Germana.Trentadue@ec.europa.eu (G.T.); Harald.Scholz@ec.europa.eu (H.S.); \\ Marcos.Otura@ec.europa.eu (M.O.) \\ * Correspondence: Alexandre.Lucas@ec.europa.eu; Tel.: +351-9617-41327
}

Received: 30 August 2018; Accepted: 30 September 2018; Published: 2 October 2018

\begin{abstract}
Exposing electric vehicles (EV) to extreme temperatures limits its performance and charging. For the foreseen adoption of EVs, it is not only important to study the technology behind it, but also the environment it will be inserted into. In Europe, temperatures ranging from $-30^{\circ} \mathrm{C}$ to $+40{ }^{\circ} \mathrm{C}$ are frequently observed and the impacts on batteries are well-known. However, the impact on the grid due to the performance of fast-chargers, under such conditions, also requires analysis, as it impacts both on the infrastructure's dimensioning and design. In this study, six different fast-chargers were analysed while charging a full battery EV, under four temperature levels $\left(-25^{\circ} \mathrm{C},-15^{\circ} \mathrm{C},+20^{\circ} \mathrm{C}\right.$, and $+40^{\circ} \mathrm{C}$ ). The current total harmonic distortion, power factor, standby power, and unbalance were registered. Results show that the current total harmonic distortion $\left(\mathrm{THD}_{\mathrm{I}}\right)$ tended to increase at lower temperatures. The standby consumption showed no trend, with results ranging from $210 \mathrm{VA}$ to $1650 \mathrm{VA}$. Three out of six chargers lost interoperability at $-25^{\circ} \mathrm{C}$. Such non-linear loads, present high harmonic distortion, and, hence, low power factor. The temperature at which the vehicle's battery charges is crucial to the current it withdraws, thereby, influencing the charger's performance.
\end{abstract}

Keywords: electric vehicles; harmonics; power quality; interoperability; fast-chargers

\section{Introduction}

Smart grids and digital technologies are set to change the global energy system in coming decades, making it more connected, sustainable, and reliable. This will have a significant and enduring effect on both energy demand and supply, according to the 2017 International Energy Agency (IEA) [1]. In trying to achieve the environmental goals set by the international community [2], communication and information are having an impact on the energy sector which has never before been observed, on the path to make it smarter. From the distributed ledger protocols to big data analysis, technologies are shaping the dynamics of services that will be offered in the future. The way machines will interact with each other to provide those services will require a multilayer analysis. Assessing interoperability between components and performances is, therefore, a crucial activity for the successful implementation of the smart grid. One of the sectors bound to suffer tremendous change is the transportation sector, particularly on-road light-duty vehicles.

The continuous growth of electric vehicles (EV) presents both a challenge and opportunity for citizens and companies. Road vehicles' electrification success depends on the charging infrastructure effectiveness to support consumers and mitigate driving-range limitations. Charging at high power means reducing the time it takes to charge the vehicles' battery. However, using high power non-linear devices in low voltage grids may cause power quality problems, namely harmonic distortions. In Europe, manufacturers are exploring different options of power in fast-charging (higher than $50 \mathrm{~kW}$ ). This represents new challenges on the grid for infrastructure design, dimensioning, and verifying 
standard conformance. This is of particular importance when such infrastructures allow multiple chargers to work simultaneously [3] or to work under adverse conditions.

Most European Member States have an EV charging infrastructure in place mostly still part of pilot projects. The first data, from the interaction between charging points and the consumers, are now known. The main challenges being addressed by the scientific community, industry and policy makers, today, are to assess the optimal ratio of cars per charger, the optimum location of the charging points, grid upgrade needs, consumer preferences, and service optimization through big data treatment.

\subsection{Interoperability}

As stated by the European Committee for Standardization(CEN), European Committee for Electrotechnical Standardization (CENELEC) and European Telecommunications Standards Institute (ETSI) Smart Grid Coordination Group (SG-CG) [4], interoperability means: "The ability of two or more networks, systems, devices, applications, or components to interwork, to exchange and use information in order to perform required functions". In this regards, interoperability within a smart grid must be considered and specified in use-cases, to develop interoperable Smart Grid systems, by design. A use-case definition provides the basis for the specification of functional and non-functional requirements, test cases, and test profiles. Based on the smart grid architecture model (SGAM) [4] framework there are five different layers of interoperability:

- Component layer, which is the hardware to connect systems or devices such as power cables.

- Communication layer, which is the communication technology (e.g., PLC or Ethernet) and the communication protocol for data transmission.

- Information layer, which is the data model to be used to ensure a common understanding of the data exchanged.

- Functional layer, specifying the functions and interactions.

- Business Layer.

The SG-CG also presents the methodology to access interoperability [4] and states that lack of interoperability can arise because manufacturers often choose different or inconsistent options, within the standard, or because the implementations have conflicting understandings of the specification. Hence, ambiguities, errors, unclear requirements, conflicting options or other factors (such as third-party interference) that could lead to non-interoperability should be investigated. Third-party interferences may come from the environment, context or event that the systems may be exposed to. One factor, among many others, is temperature. Many systems interoperate under ambient temperatures but when exposed to extreme conditions, this is not certain.

Even though we analyse the context/conditions where an EV and a fast-charger operate, the aim of the study is to analyse the performance of the process, assuming from the start that they interoperate. Exposing the systems to a third-party interference, such as extreme temperatures may, however, have an impact on this and for this reason, this theme has been addressed, as well.

\subsection{EV Fast-Charging Performance and Temperatures}

Given the importance of power adequacy of EVs, many studies have investigated their charging processes under various scenarios. Studies focus both on plug-in hybrid [5] and pure electric vehicles [6]. Authors in Reference [7] present a review of the modelling approaches to renewable energy integration. They conclude that EVs can significantly integrate the present excess of renewable energy produced. Studies focusing on the batteries themselves and the impacts of stressful conditions have been carried out, where the authors [8] observed a significant temperature increase in conditions of repeated acceleration and deceleration. The temperature dependency of charging and power consumption, especially low temperatures effects, have been demonstrated $[9,10]$ to affect the performance of EVs in different aspects. Authors in Reference [11] observe that at negative temperatures, the charging capacity is reduced as the internal resistance of the battery increases, 
causing the maximum voltage to be reached earlier [12]. In order to protect the battery, a higher voltage cannot be applied, as it would result in a reduction of the current, which would increase the charging time. The same phenomenon happens if an EV is being driven, the minimum voltage is reached earlier and the current drawn from the battery must be reduced, thus weakening acceleration capabilities. Other impacts may be observed as a reduction of regenerative braking capability, increased heating, ventilation, and air conditioning systems (HVAC) [8,11-13]. At higher temperatures $\left(>+40{ }^{\circ} \mathrm{C}\right)$, no adverse impacts are observed, both for charging and discharging, since the internal resistance decreases further. However, battery degradation and self-discharge may be faster due to higher chemical activity [14]. Even though the charging efficiency of EVs, when exposed to extreme temperatures, has been a covered subject in the literature, the harmonic distortion during charging and standby power consumption of the chargers themselves, have somehow been overlooked. Despite some impacts of low-temperature on EV performance, regions where winters are particularly severe, have observed a rising adoption of EV's, such as Norway. With an increasing market share of $22 \%$ in 2015 and a foreseen $30 \%$ in 2020, the Norwegian EV fleet may reach approximately 250,000 units, by 2020 [15]. An important factor contributing to this high rate of EV adoption, is the charging infrastructure implementation. The European Clean Power for Transport directive [16] recommends that there should be one publicly available charging point for every 10 electric cars, by 2020 . Fast-chargers are effective solutions, providing, typically, $50 \mathrm{~kW}$ of power. Since most manufacturers have chosen to use either CCS or Chademo car adapters, most fast-chargers come with both these solutions incorporated in them. However, Tesla provides a supercharger which is capable of providing $120 \mathrm{~kW}$. An EV with a $60 \mathrm{kWh}$ battery can be fully charged within an hour. This solution, however, is a proprietary one and it targets Tesla users only. There is yet a growing interest in the present development of high power chargers (HPC) which may supply up to $350 \mathrm{~kW}$, opening the market for larger vehicles. The power provided may vary from one EV to another as chargers adjust their power levels, based on the temperature, battery capacity, battery SOC, and other factors, to protect the battery. The main issue remaining to be solved is the interoperability. Vehicle owners must be assured that they can approach any charger and that their vehicle will be charged without communication or compatibility problems.

Topics for the analysis of EV-charging impacts on the distribution networks can be listed as voltage regulation, harmonic distortion levels, unbalances, additional losses, and transformers loss of lifetime. In terms of power quality, a distributed system means a more horizontally structured grid, hence, the impacts of harmonics become relevant to study in Points of Common Coupling (PCC).

Literature reports different findings regarding power quality impact from EVs. Authors modelling low-voltage systems [17], particularly in urban scenarios [18], defend that distribution networks can have limitations in EV-charging support, even for relatively low EV penetration levels. Authors in Reference [19], focusing on the residential harmonic loads and the EV charging, conclude the same by observing a potential harmonic impact, above the standard limits. Other studies suggest that low plug-in electric vehicle (PEV) penetration levels, with normal charging power, will have acceptable low harmonic levels $[20,21]$, and voltage fluctuations [22,23], however, fast-charging could cause significant voltage harmonics and losses [24]. Most of studies tend to focus only on current harmonics, addressing the main concern of the residential and normal chargers, as they are expected to have a higher penetration. Authors in Reference [3] however, address the total harmonic distortion impact of multiple fast-chargers, working at the same time, under a Point of Common Coupling (PCC). Their study calculated the voltage and current total harmonic distortion $\left(\mathrm{THD}_{\mathrm{V}}, \mathrm{THD}_{\mathrm{I}}\right)$ and Total Demand Distortion (TDD), reporting the former at $1.2 \%$ and the latter two at $12 \%$ impacts, respectively. For the charger considered, the total values measured during the constant cycle stage, complied with the standards limits stated by the Institute of Electrical and Electronics Engineers (IEEE) 519 [25] and the International Electrotechnical Commission (IEC) 61000-3-12/2-4 [26,27]. However, when considered individually, harmonics failed to comply with the limits provided by the same standards, mostly due to the 11th and 13th orders, which are likely to exceed the 5.5\% limit in IEEE 519 (5\% and 3\% 
respectively in IEC61000-2-4). Furthermore, the 23rd and 25th harmonics, even though less probable, could also be in violation of their own stated limits.

In addition to this, the study also concluded that the main limitation of the number of chargers in a multi-charger station is the harmonic limits and not just the power capacity of the upstream power transformers. When the number of EVs charging simultaneously increases, the total current also increases and causes the standard limits to decrease, reaching a point where harmonic limits have been exceeded. The limitation in installing fast-chargers is, thus, reliant on the robustness of the systems in terms of the short-circuit current and the amount of current drawn by the vehicle cluster. This clearly identifies a limit to the number of chargers to work simultaneously and hence justifies the pertinence of studying power quality impacts, under different conditions, namely temperatures. This is especially important if we consider that the temperatures in the EU may vary from approximately $-45^{\circ} \mathrm{C}$ to $+45^{\circ} \mathrm{C}$ [28]. In this study, we analysed the apparent standby power consumption, the $\mathrm{THD}_{\mathrm{I}}$, and the power factor, and observed the interoperability. Six commercial fast-chargers were studied, when submitted to ambient and extreme temperature conditions, during an EV fast-charging. The temperatures studied were $-25^{\circ} \mathrm{C},-15{ }^{\circ} \mathrm{C},+20^{\circ} \mathrm{C}$, and $+40{ }^{\circ} \mathrm{C}$.

\section{Harmonics and Standby Power}

In perfect conditions, both current and voltage are sinusoidal waves. Harmonic distortions cause a deviation from these perfect shapes, mostly due to non-linear loads, and are commonly referred to as noise or pollution. In the case of nonlinear loads, such as EV charge-controllers, current distortion often occurs, due to the existence of power electronic switches, which convert power from AC to DC. The presence or injection of these currents, in the distribution system, can distort the electricity system operator supply voltage and overload the expensive electrical distribution switchgear. In order to prevent harmonics from degrading the operator supply, standards such as the IEC 61000-3-12/2-4 [26,27] have been promoted with the aim of developing recommended practices and requirements for harmonic control, in electrical power systems. These standards have been adopted by the research community and the industry, and they describe the problems that the harmonic current distortion might cause within electrical systems, as well as the limits of such harmonics in a given system. These limits can be seen in Table 1 as a percentage of the reference current. System operators are required to supply power with certain quality levels whose limits, among others, depend on the level of voltage connection. Consumers, on the other hand, are responsible for not degrading the voltage of the utility by drawing significant nonlinear or distorted currents.

Table 1. Maximum Harmonic Current Distortion set in IEC 61000-3-12 [26].

\begin{tabular}{|c|c|c|c|c|c|c|}
\hline \multirow{2}{*}{$\begin{array}{c}\text { Minimum RSCE } \\
-\end{array}$} & \multicolumn{4}{|c|}{$\begin{array}{l}\text { Admissible Individual Harmonic Current } \\
\qquad \mathrm{I}_{\mathrm{h}} / \mathrm{I}_{\text {ref }}(\%)\end{array}$} & \multicolumn{2}{|c|}{$\begin{array}{l}\text { Admissible Harmonic } \\
\text { Parameters }(\%)\end{array}$} \\
\hline & $\mathrm{I}_{5}$ & $\mathrm{I}_{7}$ & $\mathrm{I}_{11}$ & $\mathrm{I}_{13}$ & $\mathrm{THC} / \mathrm{I}_{\mathrm{ref}}$ & $\mathrm{PWHC} / \mathrm{I}_{\mathrm{ref}}$ \\
\hline 33 & 10.7 & 7.2 & 3.1 & 2 & 13 & 22 \\
\hline 66 & 14 & 9 & 5 & 3 & 16 & 25 \\
\hline 120 & 19 & 12 & 7 & 4 & 22 & 28 \\
\hline 250 & 31 & 20 & 12 & 7 & 37 & 38 \\
\hline$\geq 350$ & 40 & 25 & 15 & 10 & 48 & 46 \\
\hline
\end{tabular}

The relative values of even harmonics, up to the order 12 , shall not exceed $16 / \mathrm{h} \%$. Even harmonics above order 12 are taken into account in THC and PWHC, in the same way as odd-order harmonics. Linear interpolation between successive $R_{S C E}$ values is permitted. $\mathrm{R}_{\mathrm{SCE}}$ : Short-circuit ratio; $\mathrm{I}_{\mathrm{h}}$ : Harmonic current component; $\mathrm{I}_{\mathrm{ref}}$ : Reference current; THC: Total Harmonic Current; PWHC: Partial Weighted Harmonic Current.

The European Norm EN 50160 [29] states the main voltage parameters and their tolerated deviation ranges at the customer's PCC, in both public low-voltage and medium-voltage electricity distribution systems. However, the load current is not relevant to EN 50160. Regarding the actual current harmonic limits, the European standards are akin to IEC, hence, only the latter will be referred to, onwards. 
The short circuit current $\left(\mathrm{I}_{\mathrm{SC}}\right)$ over the total line current $\left(\mathrm{I}_{\mathrm{L}}\right) \mathrm{I}_{\mathrm{SC}} / \mathrm{I}_{\mathrm{L}}$ ratio shows the relative size of the load, compared to the utility system. Under a linearity hypothesis, in a given point, power systems may be transformed into a Thevenin equivalent with the related impedance. The short-circuit, which may also be expressed in short-circuit power (SCP), at that point "quantifies" the equivalent impedance of the network. If the equivalent impedance is high (i.e., low SCP) the network is considered "weak" and the voltage is affected by the (harmonic) currents; if the network is strong, the voltage is not affected. It is, therefore, necessary to calculate or to measure the short-circuit current (ISC) at the PCC, where the measurements are intended to identify the limits to compare with.

Standby apparent power, on the other hand, refers to the electrical power consumed by a device when not in actual operation, but is only connected to a power source, is ready to be used. In this study, apparent power is presented in VA units, hence, both active and reactive powers are considered. This consumption is given by the continuous operation of the screen, the filters, and the other internal circuits. Some charging units have fans to mitigate the heat and the resistances, to keep a minimum temperature, in the case of low-temperature scenarios. How and when such circuits such as screens, filters, fans, or heaters work may have an impact on the apparent power consumption, in the end, which is to be paid by the final consumer. Investigating the performance of the idle time is important to mitigate the uncertainty, when carrying out similar investments. It is a crucial component for investors to integrate such "losses" and capitalize over the $8760 \mathrm{~h}$ per year, during the lifetime of each charger, which are usually always on and ready to operate, since the foreseen maintenance interventions have a very low frequency.

\section{Methodology and Test Design}

\subsection{Devices and Measurements}

The study was conducted at the European Interoperability Centre for electric vehicles and smart grids. Figure 1 shows the setup of the experiment, where the vehicle can be seen inside the chamber with the door open, for the purpose of this picture. The chargers were placed inside the chamber and the door was closed for temperature acclimatisation. The measuring equipment was maintained outside due to its temperature limitations. All measurements were performed on a Nissan Leaf $24 \mathrm{kWh}$ battery fully electric vehicle, using the corresponding Chademo adapter.

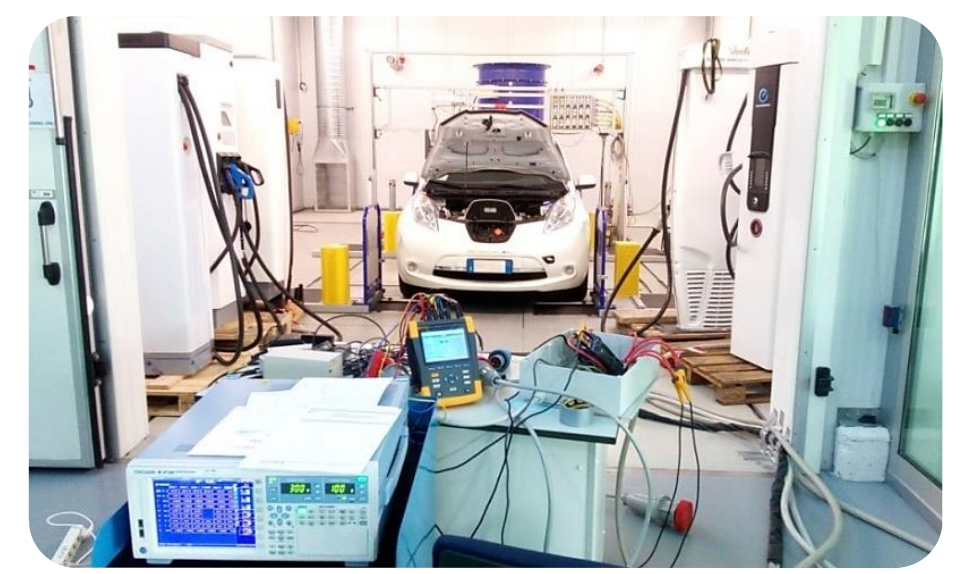

Figure 1. Fast-charging experiment implementation in the climatic chamber set-up.

The commercial fast-chargers were connected to a max. 125 A wall socket, $230 \mathrm{~V}_{\text {ph-n }}, 50 \mathrm{~Hz}$, at one end, passing through a measurement box and from the box to the charger itself. The box was specifically created to connect all voltage and current measurement clamps and can also be seen in Figure 1. The same voltage $\left(400 \mathrm{~V}_{\mathrm{ph}-\mathrm{ph}}\right)$ wall socket was used in all measurements. 
A Power Quality and Energy Analyser was used as a measurement device. The analyser model is the Fluke 437 Series II [30], $400 \mathrm{~Hz}$, set with $0.5 \mathrm{~s}$ time step, for data acquisition. The harmonics were registered up to $1050 \mathrm{~Hz}$, even though the equipment can read up to $2500 \mathrm{~Hz}$. The resolution and accuracy of the THD for both voltage and current was $0.1 \%$ and $\pm 2.5 \%$ of the reading, respectively, whereas for the phase angles it was $1^{\circ}$, with an accuracy of $\pm n \times 1^{\circ}$ (where $n$ is the harmonic order). The $\mathrm{THD}_{\mathrm{I}}$ expresses harmonic content as \% of $\mathrm{I}_{1}$ (fundamental current), as presented in Equation (1).

$$
\mathrm{THD}_{\mathrm{I}}=\frac{\sqrt{\mathrm{I}_{2}^{2}+\mathrm{I}_{3}^{2}+\mathrm{I}_{4}^{2}+\mathrm{I}_{5}^{2}+\cdots}}{\mathrm{I}_{1}}
$$

In all measurements, the Voltage Total Harmonic Distortion ( $\left.\mathrm{THD}_{\mathrm{V}}\right)$ was observed to be always below $3 \%$, hence, the study focussed only on the current total harmonic distortion $\left(\mathrm{THD}_{\mathrm{I}}\right)$.

The apparent standby power consumption was given by the Fluke in its default option (unified method), which followed Equation (2):

$$
\mathrm{S}_{\mathrm{Y}}=\sqrt{\left(\mathrm{U}_{\mathrm{A}}^{2}+\mathrm{U}_{\mathrm{B}}^{2}+\mathrm{U}_{\mathrm{C}}^{2}\right) \times\left(\mathrm{I}_{\mathrm{A}}^{2}+\mathrm{I}_{\mathrm{B}}^{2}+\mathrm{I}_{\mathrm{C}}^{2}\right)}
$$

It should be highlighted that Equation (2) was different from the fundamental apparent power. The fundamental powers $(50 \mathrm{~Hz}$ component only) were calculated using the FFT (Fast Fourier Transform) results, which were calculated according to IEC 61000-4-7 grouping into the first harmonic subgroup. Furthermore, it should be noted that there was a distinction between the $\cos \alpha$ and the Power Factor, also presented in this study. By definition, the power factor was the ratio of the real power to the apparent power. However, there were two concepts worth distinguishing, the displacement power factor and the distorted power factor. Both gave identical results for sinusoidal (non-distorted) voltage and current waveforms.

The Displacement Power Factor was caused by a reactive component in the load. If there was a capacitive component, it caused a capacitive current that led the voltage waveform by 90 degrees. Likewise, if there was an inductive component in the load, then there would be an inductive current flowing, in addition to the resistive current. The inductive current followed the voltage waveform by 90 degrees. The vector sum of the reactive currents and the resistive currents, resulted in a single current, with a phase angle before (leading) or after (lagging) the voltage waveform. The displacement power factor value was the cosine of the angle between the voltage waveform and the resultant current waveform. Distortion power factor was caused by the presence of harmonics in the current waveform, which were caused by non-linear loads [31]. The Fluke analyser used in the experiments provided such readings, as was apparent power factor, which included harmonics in the computation. In cases where nonlinear loads were connected, the current was far away from being sinusoidal, at least. The formula $S \times \cos \alpha=P$ was only valid with sinusoidal values. The " $\alpha$ " was the phase angle between the fundamental waves of current and voltage. If there were some harmonics also included, the signal shape in the systems could be expressed by a sum of the fundamental waves and integer harmonics [32].

\subsection{Climatic Chamber}

The European Interoperability Centre for EV and SG climatic test cell was designed to test light to medium duty battery electric, hybrid, or fuel cell electric vehicles, at temperatures in the range from $-30{ }^{\circ} \mathrm{C}$ to $+50{ }^{\circ} \mathrm{C}$, at a controlled level of humidity. Its $4 \mathrm{WD}$ chassis dynamometer achieved full road-simulation for speeds up to $260 \mathrm{~km} / \mathrm{h}$, accelerations up to $\pm 10 \mathrm{~m} / \mathrm{s}^{2}$, and allowed measurement of regenerative braking. Its emission measurement system was customized in order to correctly account for the intermittent functioning of the thermal engine, during hybrid vehicles testing. Discharging of the battery was either done inside the chamber on the roller bench or outside to perform the next measurement. 
The $\mathrm{THD}_{\mathrm{I}}$ measurements were done by capturing the constant part of the charging process, which was always at, approximately, between $22 \%$ and $29 \%$ state of charge (SOC). Both the car and the columns were placed inside a climatic chamber where the temperatures could be set and controlled by a SCADA system, in an adjacent room. The room temperature measurements $\left(+20^{\circ} \mathrm{C}\right)$ were done first, followed by the $+40{ }^{\circ} \mathrm{C},-16^{\circ} \mathrm{C}$, and finally $-25^{\circ} \mathrm{C}$. The measurement devices were kept outside, however, due to the device's limitations, under such extreme conditions which could cause failure or misreading. More than a hundred files were collected over several weeks, of which fifty measurements are presented ( 6 chargers, 4 temperature levels, 2 scenarios charging, and standby). The experiments had to be distributed through, approximately, three weeks in total, since, the vehicle had to be discharged once each measurement was done. In addition to this, the different levels of temperature were set in different days, since the chamber takes several hours to reach the setting points. The study did not focus on the internal circuits or disclose any manufacturers, brands or models of the chargers analysed, however, the main characteristics are shown in Table 2.

Table 2. The main characteristics of the fast-chargers.

\begin{tabular}{|c|c|c|c|}
\hline Charger & Operation & Standards/Connectors & $\begin{array}{l}\text { Dimensions and } \\
\text { Performance }\end{array}$ \\
\hline A & $\begin{array}{l}\text { Voltage: } 400 \text { Vac; Nominal } \\
\text { current (I): } 300 \text { ARMS @ } 120 \\
\text { kWDC + } 65 \text { kWAC charge }\end{array}$ & $\begin{array}{c}\text { Mode } 3 \text { and } 4 \text { IEC 61851-1:2010 NF; IEC } \\
\text { 62196-3:2012; IEC 62196-2 Mode 3, Type 2; } \\
\text { DIN 70121; IEC 61851-1/22/23/24 EV } \\
\text { com.-Chademo: BUS CAN } \\
\text { compatible-Combo 2: CPL } \\
\text { compatible-AC:Mode 3, JEVSG105; IEC } \\
\text { 61851-21-2; EN 61000-6-1/-2/-4 }\end{array}$ & $\begin{array}{c}\text { PF: 0.99; Efficiency rate } \\
\text { of } 96 \% \text {; Temperatures: } \\
-25^{\circ} \mathrm{C} \text { to }+45^{\circ} \mathrm{C} ; \\
\text { Weight: } 400 \mathrm{~kg} \text {; Noise: } 60 \\
\mathrm{~dB}\end{array}$ \\
\hline B & $\begin{array}{l}\text { Voltage: } 400 \mathrm{Vac} ; 73 \mathrm{~A}, 50 \\
\mathrm{kVA} \text {; DC power up to } 50 \mathrm{~kW} \text {; } \\
\text { AC power up to } 43 \mathrm{kVA} ; \\
\text { Max DC Output } 50 \mathrm{~kW} \text {; Max } \\
\text { DC current } 120 \mathrm{~A}\end{array}$ & $\begin{array}{c}\text { JEVS G104 (Chademo) IEC61851-23 PLC } \\
\text { (CCS/Combo-2) IEC61851-1 (AC) JEVS } \\
\text { G105 (Chademo) Combo T2 } \\
\text { (CCS/Combo-2) IEC62196 Type-2 OCPP } \\
(1.2 ; 1.5) \text { and others }\end{array}$ & $\begin{array}{l}\text { PF: } 0.98 \text {; Efficiency }> \\
93 \% \text {; Temp.: }-25^{\circ} \mathrm{C} \text { to } \\
+50{ }^{\circ} \mathrm{C} \text {; Weight: } 600 \mathrm{~kg} \text {; } \\
\text { Noise }<55 \mathrm{~dB}\end{array}$ \\
\hline $\mathrm{C}$ & $\begin{array}{l}\text { Voltage: } 400 \mathrm{~V} \text { AC } / 200-500 \\
\text { V DC; Power: from } 20 \text { to } 43 \\
\text { kW AC/from } 20 \text { to } 44 \mathrm{~kW} \\
\text { DC; Output current: 0-63 A } \\
\text { AC/0-125 A DC }\end{array}$ & $\begin{array}{c}\text { ZE Ready -1.2 Version; ZER-13-12033-DBT; } \\
\text { Chademo 0.9 certified; Chademo } 1.0 \\
\text { Compatible; NFC 15-100; CEM } \\
\text { 2004/108/CE; IEC 61309-9; } 1 \text { Chademo } \\
\text { connector + } 1 \text { Type } 2\end{array}$ & $\begin{array}{l}\text { PF: Not available }(\mathrm{N} / \mathrm{A}) \text {; } \\
\text { Efficiency: N/A; Temp.: } \\
-30{ }^{\circ} \mathrm{C} \text { to }+40{ }^{\circ} \mathrm{C} ; 350 \mathrm{~kg} ; \\
\text { Noise }<55 \mathrm{~dB}\end{array}$ \\
\hline $\mathrm{D}$ & $\begin{array}{c}\text { Voltage: } 400 \mathrm{VAC} \text {; Nominal } \\
\text { input current } 80 \mathrm{~A} ; 32 \mathrm{~A}-80 \\
\mathrm{~A} \text {; Nominal input power } 55 \\
\text { kVA; } 22 \mathrm{kVA}-55 \mathrm{kVA} \text {; Max } \\
\text { power } 50 \mathrm{~kW} \text {; Max current } \\
\text { 120 A }\end{array}$ & $\begin{array}{l}\text { JEVS G105 Chademo compliant RFID } \\
\text { system 13.56 MHz, ISO 14443 A Network } \\
\text { connection GSM/UMTS modem 10/100 } \\
\text { Base-T Ethernet }\end{array}$ & $\begin{array}{l}\text { PF:N/A; Efficiency > } \\
92 \% \text {; Temp.: }-30^{\circ} \mathrm{C} \text { to } \\
+40^{\circ} \mathrm{C} \text {; Weight: } 400 \mathrm{~kg} \text {; } \\
\text { Noise }<45 \mathrm{dBA} \text {; Standby } \\
\text { Power: } 100 \mathrm{~W} \text { (w/o } \\
\text { heater), } 1000 \mathrm{~W}\end{array}$ \\
\hline $\mathrm{E}$ & $\begin{array}{l}\text { Voltage: } 400 \mathrm{~V} \mathrm{AC} ; 143 \mathrm{~A} ; \\
\text { Max current ac } 63 \mathrm{~A} ; \text { Max } \\
\text { power ac } 43 \mathrm{~kW} \text {; Freq: } 50 / 60 \\
\text { Hz; Max DC output power } \\
50 \mathrm{~kW} \text {; Max } 120 \text { A DC }\end{array}$ & $\begin{array}{c}\text { Mode 3/4 (IEC-61851-1/23/24) Combo-2 } \\
\text { (DIN 70121) JEVS G105 (IEC-92196-3) Type } \\
2 \text { (IEC6296) tethered Cable CE/Combo-2 } \\
\text { (DIN 70121) EN61851-23 Chademo rev.0.9 } \\
\text { certified }\end{array}$ & $\begin{array}{l}\text { PF: > 0.96; Efficiency: } \\
95 \% \text {; Temp.: }-30^{\circ} \mathrm{C} \text { to } \\
+45^{\circ} \mathrm{C} \text { at nominal output } \\
\text { Power Weight: } 445 \mathrm{~kg} \\
\text { Noise: }<55 \mathrm{~dB}\end{array}$ \\
\hline $\mathrm{F}$ & $\begin{array}{l}\text { Voltage: } 400 \text { V AC Max. } \\
\text { input current: } 87 \text { A; } 50 \mathrm{~kW} \text {; } \\
\text { Max. output current Mode } 4 \text { : } \\
500 \text { V DC; } 120 \text { A; }\end{array}$ & $\begin{array}{c}\text { 4 Outlets; Connexion type mode } 4 \\
\text { Chademo/CCS; Mode2/3; GPRS or } \\
\text { Ethernet/OCPP V1.6; EV Ready: CEI } \\
\text { 60439/61851; Chademo: UTE C 15-722/C } \\
\text { 17-222; NF C 15-100: ISO 15118 }\end{array}$ & $\begin{array}{l}\text { PF: N/A; Efficiency: } 95 \% \text {, } \\
\text { Temp.:- }-30^{\circ} \mathrm{C} \text { to }+45^{\circ} \mathrm{C} \text {; } \\
\text { Forced Air. Weight: } 350 \\
\text { kg; Noise: }<55 \mathrm{~dB} ; \\
\text { Standby Power: } 700 \mathrm{~W} \\
\text { (with heater) }\end{array}$ \\
\hline
\end{tabular}

According to the specifications available, all chargers have, approximately, the same rated power, diverse charging options ( $\mathrm{AC}$ and $\mathrm{DC}$ ), and state close values in terms of performance. In terms of DC-charging, both options of CCS and Chademo were available, in all chargers. Efficiency was reported to be between $92 \%$ and $95 \%$, whereas, the power factor values (when stated) ranged from 0.96 to 0.99 . All chargers were specified to be able to withstand temperatures from at least $-25{ }^{\circ} \mathrm{C}$ 
up to $+40^{\circ} \mathrm{C}$. In some chargers, the standard lower temperature limit was $-10{ }^{\circ} \mathrm{C}$, as was the case of chargers $\mathrm{A}, \mathrm{C}, \mathrm{D}$, and $\mathrm{E}$. The extended limit of $-30^{\circ} \mathrm{C}$ came as an optional. Charger $\mathrm{B}$ and $\mathrm{F}$ came ready, by default, with an option of $-25^{\circ} \mathrm{C}$ and $-30^{\circ} \mathrm{C}$, respectively. It could be seen that different options were chosen by the manufacturer regarding this feature. In terms of materials, in general, all chargers had galvanized steel structures, aluminium casing, and stainless steel base/feet. Weight ranged from $400 \mathrm{~kg}$ to $600 \mathrm{~kg}$.

\section{Results and Discussion}

This section presents the outcomes of the experiments in terms of, the THDI values and the corresponding current behaviour, the apparent power consumption per phase, the apparent power factor, and interoperability, at all temperature levels. Furthermore, a sample of the voltages, currents, and $\mathrm{THD}_{\mathrm{I}}$, monitored during a charging process, is presented to show the voltage drop when the connection occurs. In addition to this, the results of unbalances during charging are presented and discussed.

First, in order to identify the limits of distortion, provided by the IEC 61000-3-12 standard [26], the short-circuit current value was measured at the point of common coupling (PCC), upstream of the $125 \mathrm{~A}$ plug used. An impedance meter (Impmeter 2) was used to record the short-circuit current $\mathrm{I}_{\mathrm{SC}}$. The value of $3.86 \mathrm{kA}$ was measured and taken into consideration for the short-circuit ratio $\left(\mathrm{R}_{\mathrm{SCE}}\right)$ estimation. Given the power of the chargers and considering the most unfavourable (higher) current value of the system, (82) ARMS per phase, a ratio of 47.07 (3860/81.2) was obtained. Such ratio had to be compared to the ones in the first column of Table 1, which in this case was between 33 and $66 \mathrm{R}_{\mathrm{SCE}}$. This corresponded to a total current harmonic of $16 \%$. Table 3 summarizes the $\mathrm{THD}_{\mathrm{I}}$ and corresponding currents (for the three-phases), measured for all six chargers (A to F), at the four temperature levels. Times recorded ranged from around 1.6 to $3.8 \mathrm{~min}$, which given the SOC targeted $(22 \%$ to $29 \%)$, corresponded to the maximum power stage of the charging curve. This condition was desirable in order to capture the maximum current and the corresponding THD. Otherwise, the results could be misleading, providing higher THD results, due to the low current. The times varied depending on the current that was able to been drawn, at different temperatures.

Table 3. Current total harmonic distortion at nominal current per charger, in different temperatures.

\begin{tabular}{|c|c|c|c|c|c|}
\hline \multirow{2}{*}{ Chargers } & \multirow{2}{*}{ Units } & \multicolumn{4}{|c|}{ Temperature Levels } \\
\hline & & $+40^{\circ} \mathrm{C}$ & $+20^{\circ} \mathrm{C}$ & $-15^{\circ} \mathrm{C}$ & $-25^{\circ} \mathrm{C}$ \\
\hline \multirow{2}{*}{ A } & $\mathrm{THD}_{\mathrm{I}} \mathrm{L}_{1-2-3}(\%)$ & $8.2-8.2-8.3$ & $6.3-6.1-6.9$ & $13.7-13-13.4$ & $15.8-14.3-15.1$ \\
\hline & $\mathrm{I}_{\mathrm{L} 1}-\mathrm{I}_{\mathrm{L} 2}-\mathrm{I}_{\mathrm{L} 3}(\mathrm{~A})$ & $82-81-80$ & $82-82-82$ & 28.6-28.9-28.1 & $17.7-17.8-17.3$ \\
\hline \multirow{2}{*}{ B } & $\mathrm{THD}_{\mathrm{I}} \mathrm{L}_{1-2-3}(\%)$ & 11-11.1-11 & $10.7-10.5-10.7$ & $24.3-26.5-23.2$ & $39.3-40.9-32.7$ \\
\hline & $\mathrm{I}_{\mathrm{L} 1}-\mathrm{I}_{\mathrm{L} 2}-\mathrm{I}_{\mathrm{L} 3}(\mathrm{~A})$ & 78.3-76.4-76.4 & 79.5-78.6-79.5 & 24.8-23.7-24.9 & 9.4-8-10 \\
\hline \multirow{2}{*}{$\mathrm{C}$} & $\mathrm{THD}_{\mathrm{I}} \mathrm{L}_{1-2-3}(\%)$ & 6.4-6.3-6.4 & 7.1-9.2-9.5 & $9.2-8.1-9.2$ & \multirow{2}{*}{ Failed to charge } \\
\hline & $\mathrm{I}_{\mathrm{L} 1}-\mathrm{I}_{\mathrm{L} 2}-\mathrm{I}_{\mathrm{L} 3}(\mathrm{~A})$ & $68-67-66.4$ & $69.3-68.3-67.3$ & $37.2-37.1-37$ & \\
\hline \multirow{2}{*}{$\mathrm{D}$} & $\mathrm{THD}_{\mathrm{I}} \mathrm{L}_{1-2-3}(\%)$ & 8.1-8.3-8.6 & 7.8-7.8-8.3 & $11.3-10.6-11.3$ & \multirow{2}{*}{ Failed to charge } \\
\hline & $\mathrm{I}_{\mathrm{L} 1}-\mathrm{I}_{\mathrm{L} 2}-\mathrm{I}_{\mathrm{L} 3}(\mathrm{~A})$ & 81.5-81.1-79.9 & 61.8-61.8-61.8 & 31.6-31.3-32.3 & \\
\hline \multirow{2}{*}{$\mathrm{E}$} & $\mathrm{THD}_{\mathrm{I}} \mathrm{L}_{1-2-3}(\%)$ & 4.1-4.1-4.1 & $4.4-4.5-4.3$ & 8.5-7.7-7.8 & \multirow{2}{*}{ Failed to charge } \\
\hline & $\mathrm{I}_{\mathrm{L} 1}-\mathrm{I}_{\mathrm{L} 2}-\mathrm{I}_{\mathrm{L} 3}(\mathrm{~A})$ & 77-74.7-74.8 & 77-75-75 & $30.3-28.7-28.2$ & \\
\hline \multirow{2}{*}{$\mathrm{F}$} & $\mathrm{THD}_{\mathrm{I}} \mathrm{L}_{1-2-3}(\%)$ & 8.8-8.5-8.3 & 12.1-12.1-11.1 & $16.1-15.9-15$ & $24.7-24.4-22.6$ \\
\hline & $\mathrm{I}_{\mathrm{L} 1}-\mathrm{I}_{\mathrm{L} 2}-\mathrm{I}_{\mathrm{L} 3}(\mathrm{~A})$ & $82.4-82.6-84.1$ & 79-79-82 & $42.7-42.8-44.4$ & $15.8-15.3-16.5$ \\
\hline
\end{tabular}

For the $+40^{\circ} \mathrm{C}$ and $+20^{\circ} \mathrm{C}$ scenarios, all the charger's $\mathrm{THD}_{\mathrm{I}}$ values were within standard limits $(<16 \%)$. However, at $-15{ }^{\circ} \mathrm{C}$, charger $\mathrm{B}$ and $\mathrm{F}$ became in violation of such a limit, with $24 \%$ and $16 \% \mathrm{THD}_{\mathrm{I}}$, respectively. In addition to this, at $-25^{\circ} \mathrm{C}$, all working chargers revealed to be out of the standard limit, and reached a value as high as $39.8 \%$ in the case of charger B. Overall, even though three chargers were not able to charge at $-25^{\circ} \mathrm{C}$, from Figures 2 and 3 it can be observed that there 
was a tendency to increase in the $\mathrm{THD}_{\mathrm{I}}$, as the temperature decreases. This could be explained by the reduction of current being requested by the vehicle, as the temperature decreased as well (Figure 3), thus, resulting in a direct reduction in the $T H D_{I}$ impact, as shown in Equation (1).
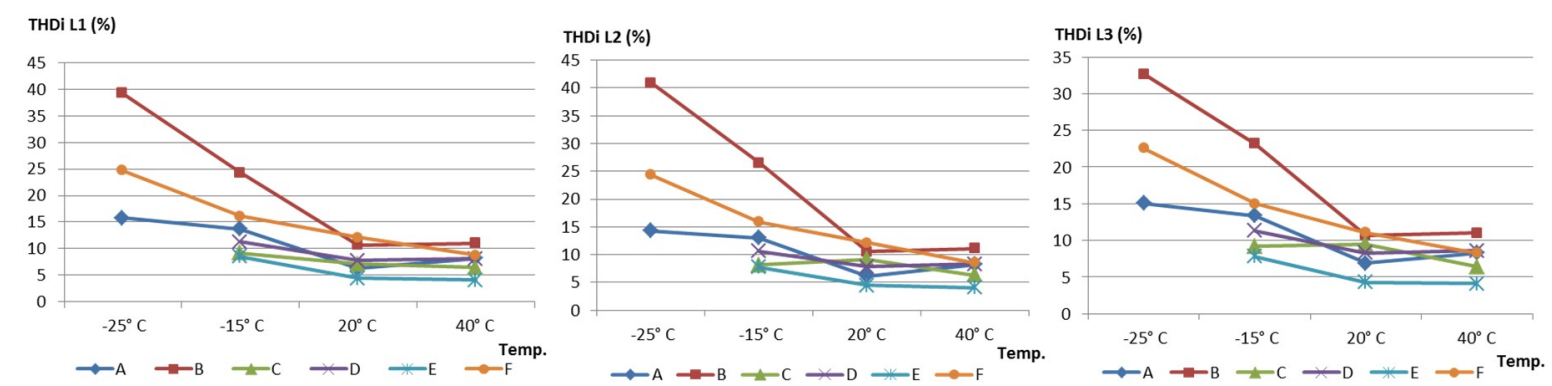

Figure 2. Current total harmonic distortion variation, with temperature per phase.
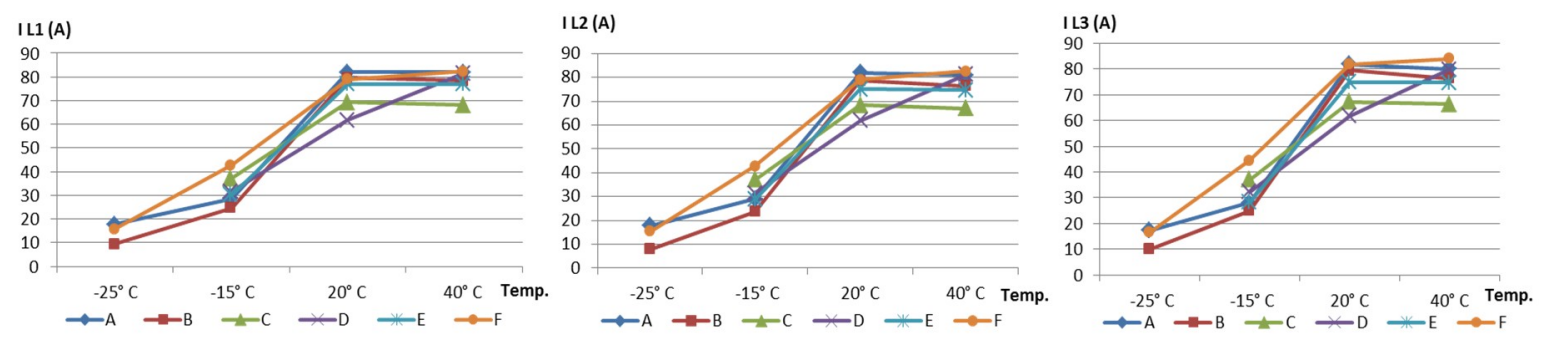

Figure 3. AC charging current (RMS) variation, with temperature per phase.

The highest values of current were measured, at the highest temperature level. On the contrary at the lowest temperature level, the least current was provided to the vehicle. The current at $-15{ }^{\circ} \mathrm{C}$ and $-25{ }^{\circ} \mathrm{C}$, reached a maximum decrease of $68 \%$ and $88 \%$, respectively, when compared to the ones at $+40{ }^{\circ} \mathrm{C}$. Figure 3 presents the RMS values of the currents per phase, in which it can be observed as an increasing trend, with the increase in temperature.

Regarding the standby performance, the power requested might have had an important impact on the investment of the charging facilities. Among others, considering such behaviour might greatly influence the equipment capitalization of losses, cables, and switchgear dimensioning, or contracted power level from the electricity provider. Acknowledging and considering such factors might mitigate investors' uncertainty regarding the price and the operational costs.

The measurements were done $30 \mathrm{~min}$ after each unit was turned on, so as to account for initialization sequences of internal circuits, which could otherwise provide misleading measurements. Apart from charger D, which specified a $1000 \mathrm{~W}$ power consumption from its heater, in standby, heater interference of apparent power could not be observed in any other chargers. The reason for this might be because the heating systems were always on, as values from charger $\mathrm{F}$ seemed to reveal (specifying a heater consumption to be about $700 \mathrm{~W}$ ). Only with an increase of temperature to $+40{ }^{\circ} \mathrm{C}$ would charger $\mathrm{F}$ increase its apparent power, which could be from the forced cooling system. On the other hand, charger D only turned on when the temperature sensor requested it, which from the technical specifications occurred below $-15^{\circ} \mathrm{C}$. Figure 4 presents all chargers' standby apparent power. However, no trend could be observed due to different construction and operational options from the manufacturers. Some chargers had a forced ventilation, permanently connected, others started at a specific temperature and even had more than one ventilation fan. To keep temperatures within a certain level, different heating systems and materials were used which allowed the chargers to work at different temperature levels. 


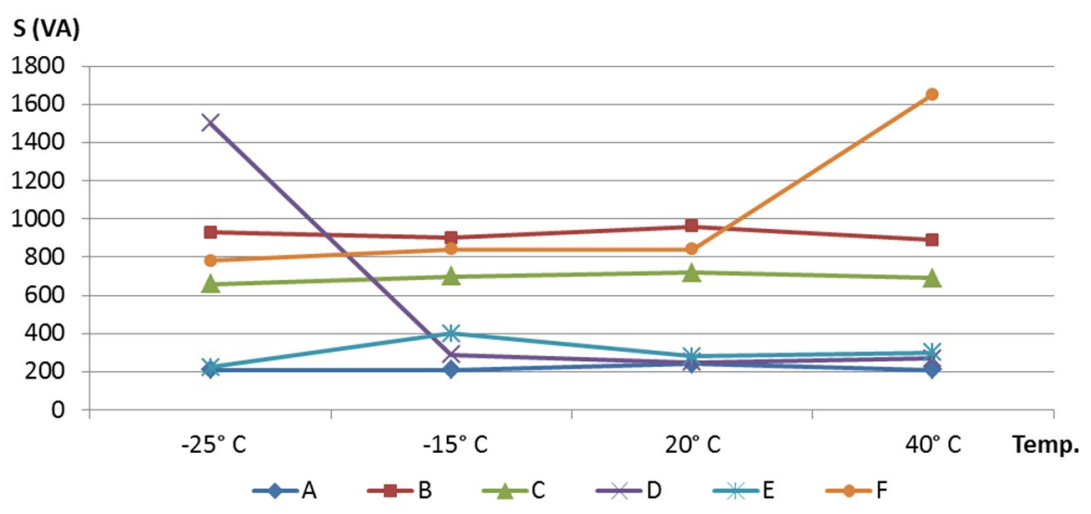

Figure 4. Total standby apparent power consumption variation, with temperature.

Apparent power should be carefully considered when designing charging installations, especially the system cables. At low values of power factor, more apparent power needs to be transported in order to provide the requested real power. As an example, if $1 \mathrm{~kW}$ of real power is required at 0.5 power factor, $2 \mathrm{kVA}$ of apparent power needs to be transferred $(1 \mathrm{~kW} \div 0.5=2 \mathrm{kVA})$. This apparent power must be produced and transmitted to the load, and is subject to losses in the production and transmission processes. Cable and electric switchgear (such as power transformers, circuit breakers, and disconnections) should also withstand these rated values of power.

The charging dynamics may be observed in Figure 5, which refers to charger D, at 40 degrees. The figure shows line to line voltages, phase currents, and neutral and $\mathrm{THD}_{\mathrm{I}}$, per phase in a time step of $0.5 \mathrm{~s}$. The values present a typical charging behaviour, where all phases tend to follow the same behaviour. A voltage drop could be observed upon the charger's connection, suffering a variation of $2.3 \%$, as compared to its steady state. In this case, the current reached a maximum value of $80-81.5 \mathrm{~A}$, and maintained a constant pattern, during the charging process. Neutral currents, as can be seen in this case, did not go beyond $3 \%$. The $\mathrm{THD}_{\mathrm{I}}$ values per phase maintained a constant pattern during the charging process, following the current's behaviour of $8.1-8.6 \%$
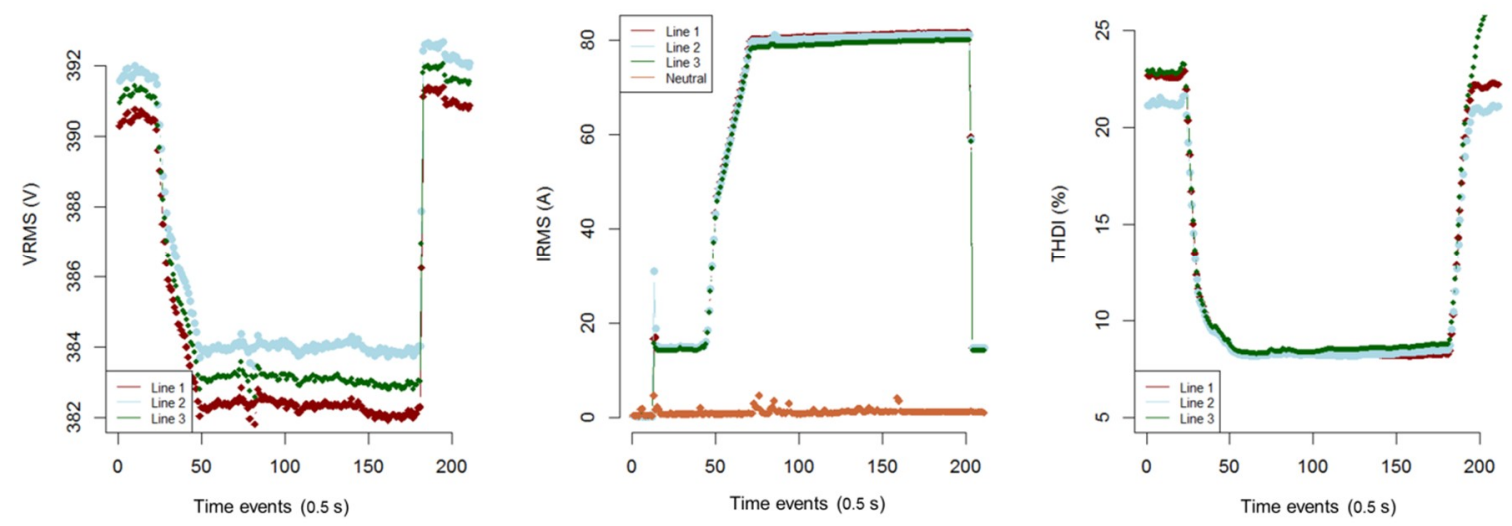

Figure 5. Three-phase voltages, currents, and $\mathrm{THD}_{\mathrm{I}}$, during the charging process for charger $\mathrm{D}$, at $40^{\circ} \mathrm{C}$.

Regarding the unbalance analysis, each of the three-phase voltage or current could be decomposed into three components. These components are known as the positive sequence, negative sequence, and the zero sequence. If the three-phase systems are considered balanced, the positive sequence component would be the normal component present in such systems. The negative sequence component, on the other hand, results from unbalanced phase-to phase currents and voltages. The phenomena of voltage unbalances cause high unbalanced currents, for example in stator windings, resulting in overheating, hence, losses and reduced motor lifetime. The negative voltage component (Vneg.) should not exceed 2\% [29]. Figure 6 shows the voltage negative and the zero sequence unbalances for all charges, in all measured temperatures. 

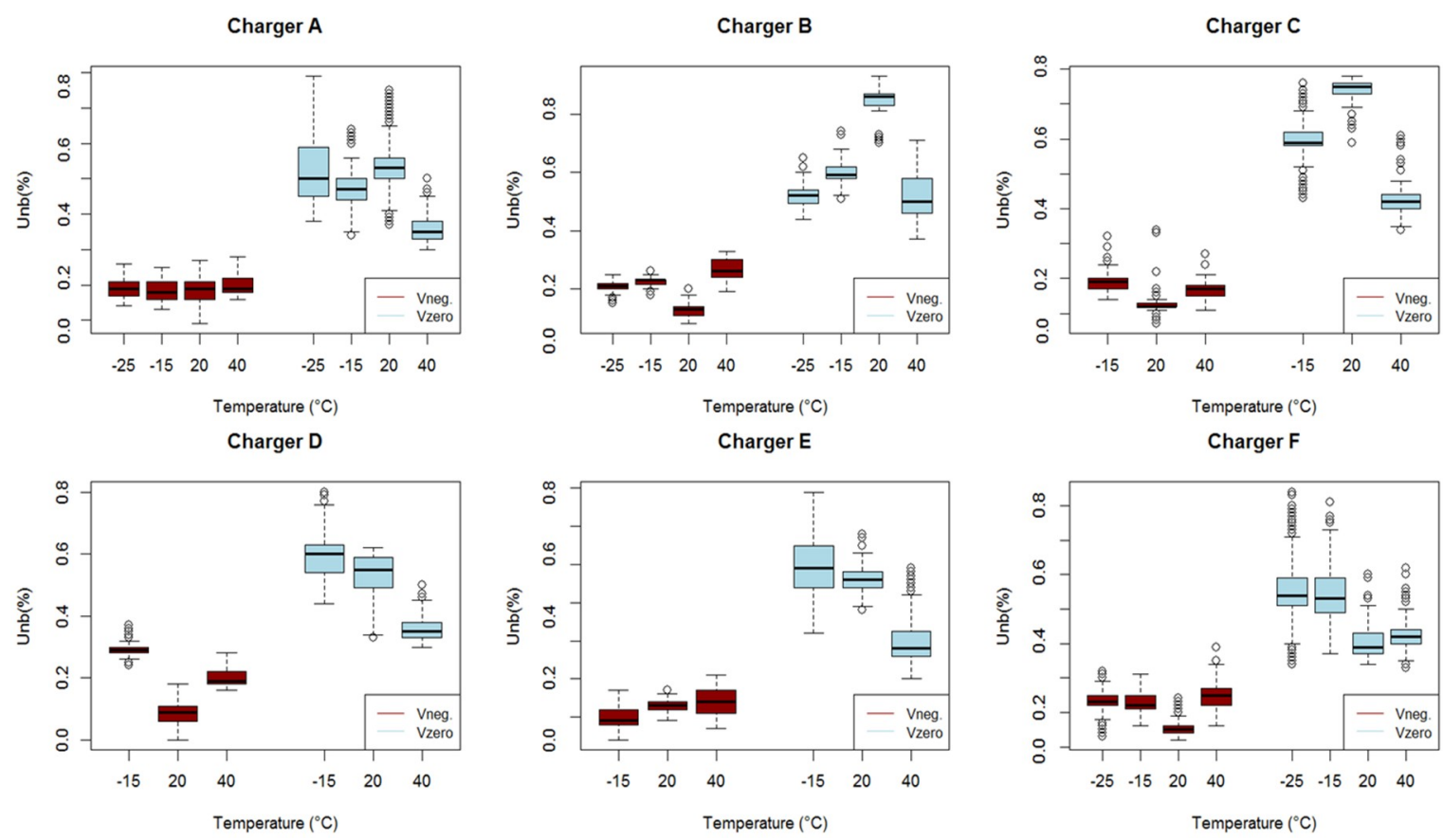

Figure 6. Boxplots of unbalances, presented by voltage negative sequence (red) and zero sequence (blue) of each charger, per temperature level measured.

As may be observed from the boxplots, the average values of the negative sequence were always below the zero sequence average. The maximum values never surpassed $2 \%$ reaching a maximum of $0.84 \%$, when charger B was measured. From the values recorded, no irregularities were recorded for the voltages or the currents.

Regarding the power factor, in general, all measurements reflected a relatively low power factor in the first and third phases. This was mainly related to the increase of the distortion power (related to harmonic content). Higher harmonic content, however, did not mean a higher reactive power. As can be seen in Figure 7, there tended to be a concentration around the same values of the Power Factor, in each of the phases. Phase 2 tended to be the one where less distorted power existed (less harmonic content), with values ranging from $0.97-1.00$. This might be explained by the fact that manufacturers chose to connect internal components, on this phase, which happened to have a low harmonic content. On the other hand, phase 3 presented the lowest values, ranging from $0.33-0.48$. Phase 1 values varied from $0.52-0.63$.

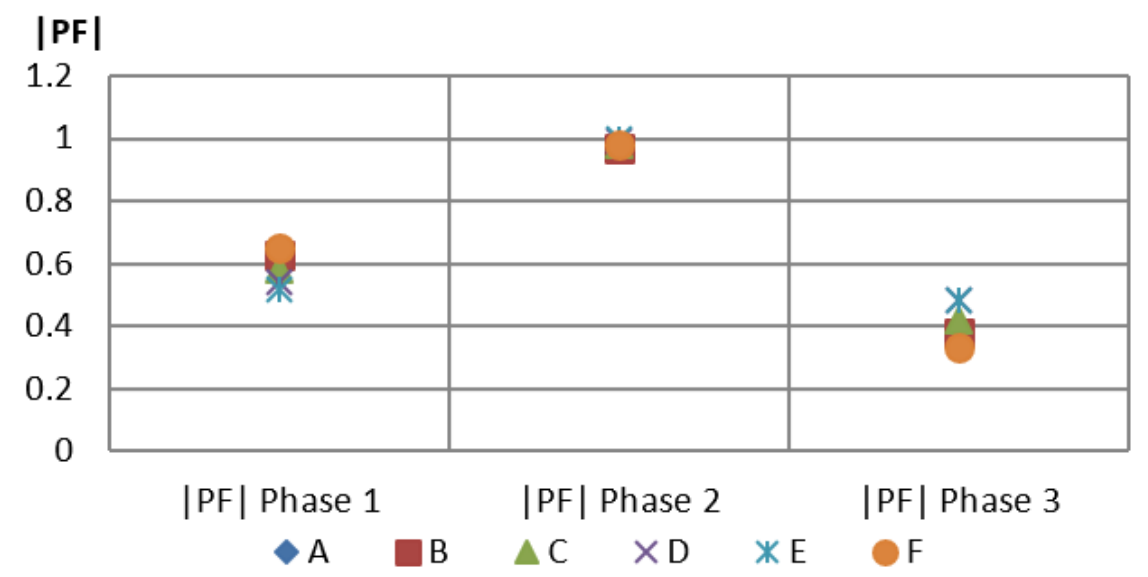

Figure 7. Fast charger's power factor per phase, during charging at ambient temperature. 
Concerning the interoperability, in order for a system to be interoperable, it must be so in several layers, as described in the SGAM [4]. This architecture helps in mapping the layer where the lack of interoperability is located. From the results, it could be observed that three fast-chargers which were operating at ambient temperatures (that is, a connected communication and exchange of information, to perform a function), failed to perform that function, when exposed to $-25{ }^{\circ} \mathrm{C}$. This was not caused by conflicting options within the standards (since they could work when placed in higher temperatures) but because they were exposed to a third party event/interference.

The reasons that caused the inability to charge were not identified during the experiments since the chargers' internal circuits were not disclosed by the manufacturers. However, possible reasons could be sensor malfunctioning at low temperatures, electronic systems, thermo-inability to heat the internal chamber of the charger to the desired conditions, impact on joints, cables, connectors or general electronic components preventing a secure charging process. However, the layer where the interoperability was affected may be inferred. In two of the three failing chargers (C and D) an error message was displayed showing, "unable to connect to vehicle" whereas, the other recognized the vehicle but displayed a message such as, "unable to initiate charge". This suggested that, in the first case, the lack of interoperability could refer to the communication layer, whereas, in the second case to the information layer, where the vehicle was recognized but operating conditions were not met to initiate the charge. However there was no error message that corresponded to each SGAM layer, so chargers $C$ and $D$ could both be referring to the information of a lack of interoperability, as well.

\section{Conclusions}

This study presented the results of the experimental activities regarding fast-charging performance, under extreme temperature conditions $\left(+40{ }^{\circ} \mathrm{C},+20^{\circ} \mathrm{C}-15{ }^{\circ} \mathrm{C},-25{ }^{\circ} \mathrm{C}\right)$. Values of $\mathrm{THD}_{\mathrm{I}}$, current, standby apparent power, and power factors were presented. $\mathrm{THD}_{\mathrm{I}}$ values increased with lower temperatures due to a decrease in requested current, by the vehicle. Three of the six chargers were out of order and unable to operate at $-25^{\circ} \mathrm{C}$. The charger's $\mathrm{THD}_{\mathrm{I}}$ values were within standard limits $(<16 \%)$. However, at $-15^{\circ} \mathrm{C}$, charger $\mathrm{B}$ and $\mathrm{F}$ became in violation of such limits, with $24 \%$ and $16 \% \mathrm{THD}_{\mathrm{I}}$, respectively. At $-25^{\circ} \mathrm{C}$, none of the chargers were within the standard limit, reaching a $\mathrm{THD}_{\mathrm{I}}$ as high as $39.8 \%$ (charger $\mathrm{B}$ ). Due to the impact of the low temperatures on vehicles and the charging process, it is advisable that the charging is done in a controlled environment, which could assure a minimum temperature for both the charger and the vehicle. This would mitigate the increase in charging time and would lower the $\mathrm{THD}_{\mathrm{I}}$. Interoperability is an area that should be further investigated, in order to assure proper operation, under diverse scenarios. As could be seen, it was not enough to just prove compatibility. Regarding apparent standby power, a maximum value of 1650 VA was registered in charger F. Such high values with low power factor should be considered whenever designing charging facilities, especially dimensioning cables, filters, and electric switchgear. The successful rollout of massive infrastructures will be a result, of both, a combination of planning and design, as well as public policies to mitigate uncertainties in infrastructure investment and associated business models.

Author Contributions: Conceptualization and methodology A.L., G.T., H.S. and X.X.; software, A.L.; validation, G.T., M.O. and H.S.; investigation, writing —original draft preparation, A.L.; writing—review and editing, A.L., G.T. and M.O.; supervision, H.S.

Funding: This research received no external funding.

Conflicts of Interest: The authors declare no conflict of interest.

\section{References}

1. IEA. Digitalization and Energy; IEA: Paris, France, 2017; p. 188.

2. Adoption of the Paris Agreement. Available online: https://unfccc.int/resource/docs/2015/cop21/eng/ 109.pdf (accessed on 1 October 2018). 
3. Lucas, A.; Bonavitacola, F.; Kotsakis, E.; Fulli, G. Grid harmonic impact of multiple electric vehicle fast charging. Electr. Power Syst. Res. 2015, 127, 13-21. [CrossRef]

4. CEN-CENELEC-ETSI Smart Grid Coordination Group: Smart Grid Information Security. Available online: https: / / ec.europa.eu/energy/sites/ener/files/documents/xpert_group1_security.pdf (accessed on 1 October 2018).

5. Green, R.C.; Wang, L.; Alam, M. The impact of plug-in hybrid electric vehicles on distribution networks: A review and outlook. Renew. Sustain. Energy Rev. 2011, 15, 544-553. [CrossRef]

6. Yilmaz, M.; Krein, P.T. Review of charging power levels and infrastructure for plug-in electric and hybrid vehicles. In Proceedings of the 2012 IEEE International Electrical Vehicle Conference, Greenville, SC, USA, 4-8 March 2012; Volume 28, pp. 2151-2169.

7. Richardson, D.B. Electric vehicles and the electric grid: A review of modeling approaches, Impacts, and renewable energy integration. Renew. Sustain. Energy Rev. 2013, 19, 247-254. [CrossRef]

8. Chacko, S.; Chung, Y.M. Thermal modelling of Li-ion polymer battery for electric vehicle drive cycles. J. Power Sources 2012, 213, 296-303. [CrossRef]

9. Lindgren, J.; Lund, P.D. Effect of extreme temperatures on battery charging and performance of electric vehicles. J. Power Sources 2016, 328, 37-45. [CrossRef]

10. Neubauer, J.; Wood, E. Thru-life impacts of driver aggression, climate, cabin thermal management, and battery thermal management on battery electric vehicle utility. J. Power Sources 2014, 259, 262-275. [CrossRef]

11. Plett, G.L. Extended Kalman filtering for battery management systems of LiPB-based HEV battery packs-Part 2. Modeling and identification. J. Power Sources 2004, 134, 262-276. [CrossRef]

12. Bullis, K. Electric Vehicles out in the Cold. MIT Technology Review. Available online: https://www. technologyreview.com/s/522496/electric-vehicles-out-in-the-cold/ (accessed on 22 November 2017).

13. Rezvanizaniani, S.M.; Liu, Z.; Chen, Y.; Lee, J. Review and recent advances in battery health monitoring and prognostics technologies for electric vehicle (EV) safety and mobility. J. Power Sources 2014, 256, 110-124. [CrossRef]

14. Merla, Y.; Wu, B.; Yufit, V.; Brandon, N.P.; Martinez-Botas, R.F.; Offer, G.J. Novel application of differential thermal voltammetry as an in-depth state-of-health diagnosis method for lithium-ion batteries. J. Power Sources 2016, 307, 308-319. [CrossRef]

15. Figenbaum, E. Perspectives on Norway's supercharged electric vehicle policy. Environ. Innov. Soc. Transit. 2015, 25, 14-34. [CrossRef]

16. Europen Commission. Directive of the european parliament and of the council on the deployment of alternative fuels infrastructure. Off. J. Eur. Union 2014, 12, 1-38.

17. Richardson, P.; Flynn, D.; Keane, A. Impact assessment of varying penetrations of electric vehicles on low voltage distribution systems. In Proceedings of the IEEE PES General Meeting, Providence, RI, USA, 25-29 July 2010; pp. 1-6.

18. Tikka, V.; Lassila, J.; Haakana, J.; Partanen, J. Case study of the effects of electric vehicle charging on grid loads in an urban area. In Proceedings of the 2011 2nd IEEE PES International Conference and Exhibition on Innovative Smart Grid Technologies, Manchester, UK, 5-7 December 2011; pp. 1-7.

19. Bass, R.; Harley, R.; Lambert, F.; Rajasekaran, V.; Pierce, J. Residential Harmonic Loads and EV Charging. In Proceedings of the Power Engineering Society Winter Meeting, Columbus, OH, USA, 28 January1 February 2001; Volume 2, pp. 803-808.

20. Basu, M.; Gaughan, K.; Coyle, E. Harmonic distortion caused by EV battery chargers in the distribution systems network and its remedy Harmonic distortion caused by EV battery chargers in the distribution. In Proceedings of the 39th International Universities Power Engineering Conferences, Bristol, UK, 6-8 September 2004; pp. 869-873.

21. Lo, E.W.C.; Sustanto, D.; Fok, C.C. Harmonic Load Flow Study for Electric Vehicle Chargers. In Proceedings of the International Conference on Power Electronics and Drive Systems, PEDS'99, Hong Kong, China, 27-29 July 1999; pp. 495-500.

22. Zimmerman, R.; Bass, N. Impacts of Electric Vehicle Charging on Electric Power Distribution Systems-OTREC-SS-731; Portland State University: Portland, OR, USA, 2013. 
23. Melo, N.; Mira, F.; de Almeida, A.; Delgado, J. Integration of PEV in Portuguese distribution grid: Analysis of harmonic current emissions in charging points. In Proceedings of the 11th International Conference on Electrical Power Quality and Utilisation, Lisbon, Portugal, 17-19 October 2011; pp. 1-6.

24. Foosnæs, A.H.; Jensen, A.N.; Nordentoft, N.C. Case Studies of Grid Impacts of Fast Charging; Report D 4.4.3 and D 4.4.4; Edison Consortium: Copenhagen, Denmark, 2011; p. 66.

25. IEEE 519-1992. IEEE Recommended Practices and Requirements for HArmonics Control in Electric Power Systems (ANSI); IEEE: New York, NY, USA, 1992.

26. IEC. IEC 61000-3-12 Electromagnetic Compatibility (EMC)_Part 3-12: Limits_Limits for Harmonic Currents Produced by Equipment Connected to Public Low-Voltage Systems with Input Current $>16$ A and $\leq 75$ A Per Phase; IEC: Geneva, Switzerland, 2011.

27. IEC. IEC 61000-2-4 Electromagnetic Compatibility (EMC)—Part 2-4: Environment_Compatibility Levels in Industrial Plants for Low-Frequency Conducted Disturbances, ed. 2.0; IEC: Geneva, Switzerland, 2014.

28. World Meteorological Organization-Temperatures and Extreme Weather Conditions. Available online: https:/ / public.wmo.int/en/media/news/high-temperatures-and-extreme-weather-continue (accessed on 1 November 2017).

29. European Commission. EN 50160:2010, Voltage Characteristics in Public Distribution Systems; European Standard; European Commission: Brussels, Belgium, 2010.

30. Fluke, Fluke and Powerlog. Available online: https://www.fluke.com/en/support/software-downloads (accessed on 1 November 2017).

31. Power-Factor. Available online: http://www.power-factor.co.nz/distortion-power-factor.php (accessed on 1 November 2017).

32. Siemens Technical Note-Difference between Cosine Phi and the Power Factor. Available online: https:/ / support.industry.siemens.com/cs / document/51402748/7km-difference-between-cosinephi-and-the-power-factor?dti=0\&lc=en-WW (accessed on 1 November 2017).

(C) 2018 by the authors. Licensee MDPI, Basel, Switzerland. This article is an open access article distributed under the terms and conditions of the Creative Commons Attribution (CC BY) license (http:/ / creativecommons.org/licenses/by/4.0/). 